\title{
Lung function and chronic respiratory symptoms of pig farmers: focus on exposure to endotoxins and ammonia and use of disinfectants
}

\author{
Liesbeth Preller, Dick Heederik, Jan S M Boleij, Peter F J Vogelzang, Martin J M Tielen
}

Department of

Epidemiology and

Public Health,

Wageningen

Agricultural

University, The

Netherlands

L Preller

D Heederik

J S M Boleij

Department of Air

Quality, Wageningen

Agricultural Universi-

ty, The Netherlands

L Preller

Animal Health Service in The Southern

Netherlands, Boxtel,

The Netherlands

L Preller

M J M Tielen

Board for the

Authorisation of

Pesticides,

Wageningen, The

Netherlands

J S M Boleij

Department of

Occupational

Medicine, University

of Nijmegen, The

Netherlands

P F J Vogelzang

Correspondence to:

Dr D J J Heederik,

Wageningen Agricultural

University, Department of

Epidemiology and Public

Health, PO Box 238, 6700

AE Wageningen, The

Netherlands.

Accepted 19 June 1995

\begin{abstract}
Objectives-The prevalence of chronic respiratory symptoms among pig farmers is known to be high, but the aetiology of these symptoms is not yet unravelled. Long term average exposure to dust was evaluated, endotoxins and ammonia and use of disinfectants were compared with chronic respiratory symptoms and depressed base line lung function.

Methods-A cross sectional study was performed among 194 Dutch pig farmers, of whom 100 had not and 94 had chronic respiratory symptoms. Exposureresponse relations were evaluated with multiple logistic and linear regression analysis. Estimates of long term average exposure were based on two personal exposure measurements, taken on one day in summer and one day in winter. Information on use of disinfectants and disinfection procedures was assessed by a walk through survey and interview by telephone.
\end{abstract}

Results-Exposure to dust, endotoxins, and ammonia were not related to chronic respiratory symptoms. Duration of the disinfection procedure and pressure used at disinfection were strongly and positively related to chronic respiratory symptoms. A significant inverse association between base line lung function and endotoxin exposure was found only among asymptomatic farmers. Ammonia exposure and duration of the disinfection procedure were significantly associated with base line lung function in the entire population.

Conclusion-Results suggest that use of disinfectants is an important aetiological factor in chronic respiratory health effects of pig farmers. This factor has not been studied before. Results also suggest an aetiological role for exposure to endotoxins and ammonia in development of chronic respiratory health effects, but longitudinal studies with detailed exposure assessment strategies are required to assess their roles.

(Occup Environ Med 1995;52:654-660)

Keywords: occupational epidemiology, occupational exposure, respiratory disease

Studies performed since 1977 in countries in north America and Europe showed high prevalences of acute and chronic respiratory symptoms among pig farmers. The same studies suggested that major base line lung function variables (forced vital capacity (FVC) and forced expiratory volume in one second $\left.\left(F_{E V}\right)_{1}\right)$ seem not to differ largely from expected values. ${ }^{1-5}$ The aetiology of these respiratory health effects remains until now indistinct. Pig farmers are exposed to a variety of health hazards such as organic dusts and their constituents, gases, chemicals used for disinfection of buildings, and climatic conditions. Recent epidemiological studies were focused on the potential health hazard of exposure to high levels of endotoxins, and to a lesser extent to other components of organic dusts. Reported relations between measured exposures and chronic respiratory health effects are sparse. Heederik $e t a l^{6}$ and Zejda $e t$ $a l^{7}$ reported associations between base line lung function and exposure to endotoxins. In their studies exposure was based on static measurements in swine confinement buildings over one or two days.

In our study we assessed personal exposure of inhalable dust, endotoxins, and ammonia and evaluated their association with base line lung function and chronic respiratory symptoms. In this study we also investigated disinfectants as potential aetiological factors. Several case studies have been described with respiratory symptoms, including asthma, induced by disinfectants. ${ }^{8-14}$ These agents have, however, been overlooked as possible causes of respiratory health effects in pig farmers. The questionnaire based evaluation that preceded this study, showed that farmers reported more asthma like symptoms with more frequent disinfection (unpublished data). This study describes associations between chronic respiratory symptoms and base line lung function and determinants of exposure already mentioned.

\section{Material and methods}

POPULATION AND HEALTH DATA

The population consisted of 194 pig farmers who lived in the two south eastern provinces of The Netherlands; 94 with two or more chronic respiratory symptoms (chronic cough, chronic phlegm, ever wheezing, frequent wheezing, shortness of breath, and chest tightness (asthma)) and 100 without these symptoms. The population was derived from a group of 1133 male owners of pig farms who had completed a self administered questionnaire and who worked at least five hours a day 
in pig farming. Presence of chronic respiratory symptoms was investigated with the Dutch shortened version of the British MRC questionnaire, ${ }^{15}$ as part of a self administered questionnaire. This was subsequently checked in a medical survey held in the winter of 1990-1. All 94 farmers who had reported two or more chronic respiratory symptoms were included in the study. The 100 symptomless farmers who were taken as controls were randomly selected out of the group of the 145 farmers with confirmed absence of symptoms, who were randomly selected from the farmers who had reported no chronic respiratory symptoms in the questionnaire. In the medical survey, forced expiratory lung function measurements were conducted with a Vicatest-V spirometer (Mijnhardt, Bunnik, The Netherlands). The procedure of testing and selecting of variables was carried out according to standards of the European Community of Coal and Steel. ${ }^{16}$ Lung function tests were taken between 0830 and 1515 . Variables included in the study were: forced vital capacity (FVC), forced expiratory volume in one second $\left(\mathrm{FEV}_{1}\right)$, maximum mid-expiratory flow (MMEF: forced expiratory flow between $25 \%$ and $75 \%$ of FVC), and peak expiratory flow (PEF).

EXPOSURE DATA AND DISINFECTION

Personal inhalable dust and personal ammonia samples were taken during one work shift in summer and one in winter. Measurements took on average $8 \cdot 3$ (SD $0 \cdot 6$, range $5 \cdot 2-10 \cdot 4$ ) hours. Ammonia exposure was assessed in duplicate with a passive monitoring method. ${ }^{17}$ Basically, GF-A glass fibre filters (diameter $2.4 \mathrm{~cm}$ ) were coated with a saturated solution of tartaric acid in diethylether and placed in a badge. A Teflon filter was used for an entrance membrane. After sampling, $20 \mathrm{ml}$ of demineralised water was added to the glass fibre filters, which were placed in an ultrasonic bath for 15 minutes. Samples were further analysed according to a modified indophenol detection method, ${ }^{18}$ and the concentration was assessed by spectrophotometry. The exposure concentration was expressed as time weighted average exposure. For 159 farmers exposure could be assessed on two days. For them, the geometric mean of both exposure concentrations was used as a measure of exposure in epidemiological analyses. The procedures for measurement of dust exposure and analysis of endotoxins in dust samples have been described elsewhere. ${ }^{19} 20$ A mathematical modelling technique with regression equations reported elsewhere ${ }^{21}$ was used to estimate long term average exposure. Basically, associations were measured between exposure level as a dependent variable and farm characteristics and time spent on activities during sampling as independent variables. Subsequently, regression equations, data on farm characteristics and time spent on activities in pig farming in two full weeks, were used to estimate long term average exposure to dust and endotoxins. For 161 farmers data were available on long term average dust and endotoxin exposure.
Pig farms in the study comprised on average 19 compartments. Compartments in the farrowing and finishing section, and in the section with weaned piglets, are small. After emptying a compartment, when animals are brought to another section, compartments are cleaned. Most of the 1133 farmers who completed the questionnaire regularly disinfect after cleaning. For the 194 subjects who were included in this study, information on use, type, and quantity of disinfectant was obtained during a visit to the farm. All visits were done by the same trained interviewer. Type of disinfectant was classified as chloramine- $T$, quaternary ammonium compounds, quaternary ammonium compounds combined with aldehydes (glutaraldehyde, glyoxal, formaldehyde), a combination of these compounds, and other compounds. Thirty out of 194 farmers did not use disinfectants. As preliminary analyses suggested associations between disinfection and respiratory health, additional information on disinfection procedures was obtained in an interview by telephone. Information was obtained on: frequency of disinfection on the farm, frequency of disinfection by the farmer, means of application, pressure used, duration of procedure, time until re-entering compartments after disinfection, and use of personal protection equipment during mixing and application of disinfectants. Out of the 164 farmers with disinfectants 150 participated in the interview.

\section{DATA ANALYSIS}

Associations between respiratory health and determinants of exposure were evaluated in multiple linear regression analysis (PROC REG) for lung function and multiple logistic regression analysis (PROC LOGISTIC) for chronic respiratory symptoms. Associations with lung function were adjusted for age, standing height and smoking (pack-years). Associations with respiratory symptoms were adjusted for age and smoking (current smoking). All exposure variables and aspects of the disinfection procedure were evaluated and retained in the models if they were associated with health outcomes. Excluded variables were evaluated for confounding effects. In all models, log transformed values were used for exposure to endotoxins, dust, and ammonia. Statistical analyses were performed with SAS/PC version $6 \cdot 04$.

\section{Results}

Table 1 shows characteristics of the entire population and of the groups with two or more and without chronic respiratory symptoms (chronic cough, chronic phlegm, ever wheezing, frequent wheezing, shortness of breath, and chest tightness (asthma)). In the entire population, average FVC and PEF exceeded predicted values, $\mathrm{FEV}_{1}$ was about equal to the control value, and other lung function variables were below control values. The largest difference from the control value was found for MMEF, which was on average 
Table 1 Characteristics of entire population of pig farmers, and of farmers with and without chronic respiratory symptoms*

\begin{tabular}{|c|c|c|c|}
\hline & $\begin{array}{l}A l l \\
(n=194)\end{array}$ & $\begin{array}{l}\text { Asymptomatic } \\
(n=100)\end{array}$ & $\begin{array}{l}\text { Symptomatic } \\
(n=94)\end{array}$ \\
\hline Age (y (SD)) & $38(10)$ & $36(9)$ & $40(9)$ \\
\hline (y (SD)) & $15(8)$ & $13(8)$ & $16(8)$ \\
\hline $\begin{array}{l}\text { Standing height } \\
\text { (cm (SD)) }\end{array}$ & $177(6)$ & $178(6)$ & $177(6)$ \\
\hline $\begin{array}{l}\text { Smoking (\%): } \\
\text { Current } \\
\text { Ex-smoker } \\
\text { Never-smoker }\end{array}$ & $\begin{array}{l}32 \\
31 \\
37\end{array}$ & $\begin{array}{l}18 \\
33 \\
49\end{array}$ & $\begin{array}{l}47 \\
30 \\
23\end{array}$ \\
\hline $\begin{array}{l}\text { Baseline lung functic } \\
\text { FVC (1) } \\
\text { FEV (1) } \\
\text { PEF (1/s) } \\
\text { MMEF (1/s) }\end{array}$ & $\begin{array}{c}\text { on }(\% \text { predic } \\
108(13) \\
101(17) \\
107(24) \\
82(31)\end{array}$ & $\begin{array}{l}\text { edt (SD)): } \\
111(13) \\
106(15) \\
113(23) \\
91(29)\end{array}$ & $\begin{array}{r}105(13) \ddagger \\
95(15) \ddagger \\
101(23) \ddagger \\
72(29) \ddagger\end{array}$ \\
\hline
\end{tabular}

${ }^{\star}$ Chronic cough, chronic phlegm, ever wheezing, frequent wheezing, shortness of breath, and chest tightness (asthma): no $v$ one or more.

tAccording to Quanjer. ${ }^{16}$

łLower than in asymptomatic farmers $(t$ test, $\mathrm{P}<0.01)$.

Table 2 Disinfection procedures in entire population of pig farmers, and in farmers with and without chronic respiratory symptoms*

\begin{tabular}{|c|c|c|c|}
\hline & $\begin{array}{l}\text { All } \\
(n=150) \\
n(\%)\end{array}$ & $\begin{array}{l}\text { Asymptomatic } \\
(n=74) \\
n(\%)\end{array}$ & $\begin{array}{l}\text { Symptomatic } \\
(n=76) \\
n(\%)\end{array}$ \\
\hline $\begin{array}{l}\text { Frequency on farmt: } \\
2 \text { Times/week } \\
1 \text { Time/week } \\
1 \text { Time/2 weeks } \\
\text { Less often }\end{array}$ & $\begin{array}{l}44(29 \cdot 5) \\
60(40 \cdot 3) \\
23(15 \cdot 4) \\
22(14 \cdot 8)\end{array}$ & $\begin{array}{r}21(28 \cdot 8) \\
29(39 \cdot 7) \\
9(12 \cdot 3) \\
14(19 \cdot 2)\end{array}$ & $\begin{array}{r}23(30 \cdot 3) \\
31(40 \cdot 8) \\
14(18 \cdot 4) \\
8(10 \cdot 5)\end{array}$ \\
\hline $\begin{array}{l}\text { Pressure: } \\
\text { No pressure } \\
\text { Low (<20 bar) } \\
\text { Medium }(20-50 \text { bar }) \\
\text { High ( }>50 \text { bar })\end{array}$ & $\begin{array}{l}21(14 \cdot 0) \\
99(66 \cdot 0) \\
20(13 \cdot 3) \\
10(6 \cdot 7)\end{array}$ & $\begin{array}{c}13(17 \cdot 6) \\
52(70 \cdot 3) \\
8(10 \cdot 8) \\
1(1 \cdot 4)\end{array}$ & $\begin{array}{r}8(10 \cdot 5) \\
47(61 \cdot 8) \\
12(15 \cdot 8) \\
9(11 \cdot 8)\end{array}$ \\
\hline $\begin{array}{l}\text { Type of applicationt: } \\
\text { Pressure washer } \\
\text { Foam washer } \\
\text { Watering can } \\
\text { Spray washer }\end{array}$ & $\begin{array}{c}118(79 \cdot 2) \\
14(9 \cdot 4) \\
10(6 \cdot 7) \\
7(4 \cdot 7)\end{array}$ & $\begin{array}{c}53(72 \cdot 6) \\
10(13 \cdot 7) \\
6(8 \cdot 1) \\
4(5 \cdot 5)\end{array}$ & $\begin{array}{l}65(85 \cdot 5) \\
4(5 \cdot 3) \\
4(5 \cdot 3) \\
3(3 \cdot 9)\end{array}$ \\
\hline $\begin{array}{l}\text { Time to re-entry after di } \\
<\text { Half a day } \\
\text { Half a day } \\
\text { One day }\end{array}$ & $\begin{array}{l}37(25 \cdot 0) \\
25(16 \cdot 9) \\
86(58 \cdot 1)\end{array}$ & $\begin{array}{l}22(29 \cdot 7) \\
11(14 \cdot 9) \\
41(55 \cdot 4)\end{array}$ & $\begin{array}{l}15(20 \cdot 3) \\
14(18 \cdot 4) \\
45(60 \cdot 8)\end{array}$ \\
\hline $\begin{array}{l}\text { Protection during disinf } \\
\text { No } \\
\text { Yes }\end{array}$ & $\begin{array}{l}83(55 \cdot 3) \\
66(44 \cdot 0)\end{array}$ & $\begin{array}{l}41(55.4) \\
33(44 \cdot 6)\end{array}$ & $\begin{array}{l}42(55 \cdot 3) \\
33(43 \cdot 4)\end{array}$ \\
\hline $\begin{array}{l}\text { Protection during mixin } \\
\text { No } \\
\text { Yes }\end{array}$ & $\begin{array}{r}102(68 \cdot 0) \\
46(30 \cdot 7)\end{array}$ & $\begin{array}{l}51(68 \cdot 9) \\
22(29 \cdot 7)\end{array}$ & $\begin{array}{l}51(67 \cdot 1) \\
24(31 \cdot 6)\end{array}$ \\
\hline $\begin{array}{l}\text { Duration of disinfection } \\
<5 \mathrm{~min} \\
5-10 \mathrm{~min} \\
>10 \mathrm{~min}\end{array}$ & $\begin{array}{l}68(45 \cdot 3) \\
58(38 \cdot 7) \\
24(16 \cdot 0)\end{array}$ & $\begin{array}{c}38(51 \cdot 4) \\
30(40 \cdot 5) \\
6(8 \cdot 1)\end{array}$ & $\begin{array}{l}30(39 \cdot 5) \\
28(36 \cdot 8) \\
18(23 \cdot 7)\end{array}$ \\
\hline
\end{tabular}

*Chronic cough, chronic phlegm, ever wheezing, frequent wheezing, shortness of breath, and chest tightness (asthma): no $v$ one or more.

†Total not equal to $100 \%$, some observations not classifiable.

Table 3 Exposure to endotoxins and ammonia in entire population of pig farmers, and in farmers with and without chronic respiratory symptoms*

\begin{tabular}{lccccc}
\hline & $n$ & $\begin{array}{l}\text { Arithmetic } \\
\text { mean }\end{array}$ & $\begin{array}{l}\text { Geometric } \\
\text { mean }\end{array}$ & $\begin{array}{l}\text { Geometric } \\
\text { SD }\end{array}$ & (Range) \\
\hline Dust $\left(\mathrm{mg} / \mathrm{m}^{3}\right):$ & & & & & \\
$\quad$ All & 161 & 2.7 & 2.6 & 1.3 & $(0.9-5.9)$ \\
Asymptomatic & 83 & 2.7 & 2.7 & 1.3 & $(1.5-4.5)$ \\
Symptomatic & 78 & 2.6 & 2.5 & 1.3 & $(0.9-5.9)$ \\
Endotoxins (ng/m $\left.{ }^{3}\right):$ & & & & & \\
$\quad$ All & 161 & 112 & 105 & 1.4 & $(41.4-316)$ \\
Asymptomatic & 83 & 111 & 104 & 1.4 & $(41.4-216)$ \\
Symptomatic & 78 & 113 & 106 & 1.5 & $(43.7-316)$ \\
Ammonia (mg/m $\left.{ }^{3}\right):$ & & & & & \\
All & 159 & 1.7 & 1.6 & 1.6 & $(0.3-4 \cdot 2)$ \\
Asymptomatic & 79 & 1.8 & 1.6 & 1.7 & $(0.4-4 \cdot 2)$ \\
Symptomatic & 80 & 1.6 & 1.5 & 1.6 & $(0.3-3.7)$ \\
\hline
\end{tabular}

*Chronic cough, chronic phlegm, ever wheezing, frequent wheezing, shortness of breath, and chest tightness (asthma): no $v$ one or more.
$82 \%$ of the predicted value. All lung function variables expressed as percentage of predicted were lower in symptomatic than in asymptomatic farmers $(t$ test, $\mathrm{P}<0.01)$. The largest difference was nearly $20 \%$ and was found for MMEF. Average age, years in pig farming, and prevalence of current smoking were higher among cases. Differences in lung function between symptomatic and asymptomatic farmers, as a percentage of predicted value, remained after adjustment for smoking in the multiple linear regression analysis.

Of the 150 farmers interviewed on disinfection procedures, only one asymptomatic farmer $(1.4 \%) v$ nine symptomatic farmers $(11 \cdot 8 \%)$ used high pressure for disinfection (table 2). Six (8.1\%) asymptomatic farmers spent more than 10 minutes on disinfection each time, compared with 18 (23.7\%) symptomatic farmers. For other aspects of disinfection the distribution was similar in both groups. Average exposure to dust was $2 \cdot 7$ $\mathrm{mg} / \mathrm{m}^{3}$, to endotoxins $112 \mathrm{ng} / \mathrm{m}^{3}$, and to ammonia $1.7 \mathrm{mg} / \mathrm{m}^{3}$ (table 3). Exposures did not differ between symptomatic and asymptomatic farmers.

In multiple logistic regression analysis, medium pressure or high pressure, and spending more than 10 minutes on disinfection each time were significantly and positively associated with respiratory symptoms (table 4), with estimated odds ratios (ORs) of $7 \cdot 1$ and $4 \cdot 2$, respectively. Medium and high pressure were combined in the analysis because the distribution would yield a very large confidence interval (CI) for the high pressure group. In the analysis, no difference was found between disinfection for less than five minutes and five to 10 minutes. These two categories were taken together in the analysis. Level of exposure to dust, endotoxins, and ammonia, quantity of disinfectants used in one year, and type of disinfectant were not associated with respiratory symptoms. These variables did not affect estimates of other variables, and were therefore not included in the model.

For 106 farmers a complete data set was available to test associations between lung function and exposure to endotoxins and ammonia and disinfection procedures. Log

Table 4 Multiple logistic regression analysis on chronic respiratory symptoms ${ }^{*}$ and disinfection procedure amon 150 pig farmers ( $n=74$ without symptoms, $n=76$ with symptoms)

\begin{tabular}{|c|c|c|}
\hline & OR $(95 \% C I)$ & $P$ value \\
\hline $\begin{array}{l}\text { Age (per } 10 \text { y) } \\
\text { Current smoking (yes/no) }\end{array}$ & $\begin{array}{l}1 \cdot 7(1 \cdot 1-2 \cdot 4) \\
3.3(1 \cdot 5-7 \cdot 1)\end{array}$ & $\begin{array}{l}0.012 \\
0.003\end{array}$ \\
\hline $\begin{array}{l}\text { Pressure: } \\
\text { Low } v \text { no } \\
\text { Medium/high } v \text { no }\end{array}$ & $\begin{array}{l}2 \cdot 1(0 \cdot 7-6 \cdot 1) \\
7 \cdot 1(1 \cdot 9 \quad 27 \cdot 1)\end{array}$ & $\begin{array}{l}0.194 \\
0.004\end{array}$ \\
\hline $\begin{array}{l}\text { Duration: } \\
>10 \mathrm{~min} v<10 \mathrm{~min}\end{array}$ & $4 \cdot 2(1.4-12 \cdot 7)$ & 0.010 \\
\hline
\end{tabular}

${ }^{*}$ Chronic cough, chronic phlegm, ever wheezing, frequent wheezing, shortness of breath, and chest tightness (asthma): no $v$ one or more. 
Table 5 Multiple regression analysis of lung function on endotoxin exposure, ammonia exposure and disinfection procedure in the total population and stratified for chronic respiratory symptoms* (adjusted for age, standing height, and smoking habits (pack-years))

\begin{tabular}{|c|c|c|c|c|c|c|c|c|c|}
\hline & \multicolumn{3}{|c|}{$A l l(n=106)$} & \multicolumn{3}{|c|}{ Asymptomatic farmers $(n=51)$} & \multicolumn{3}{|c|}{ Symptomatic farmers $(n=55)$} \\
\hline & $b$ & (SEM) & $P$ value & $b$ & (SEM) & Pvalue & $b$ & (SEM) & Pvalue \\
\hline $\begin{array}{l}\text { FVC (1): } \\
\text { No } v \text { low/medium pressure } \\
\text { High } v \text { low/medium pressure } \\
>10 v<10 \text { minutes } \\
\text { Endotoxin exposure } \\
\text { Ammonia exposuret }\end{array}$ & $\begin{array}{r}0.05 \\
-0.26 \\
-0.48 \\
-0.25 \\
-0.05\end{array}$ & $\begin{array}{l}0 \cdot 18 \\
0 \cdot 27 \\
0 \cdot 18 \\
0 \cdot 18 \\
0 \cdot 13\end{array}$ & $\begin{array}{l}0.399 \\
0 \cdot 168 \\
0 \cdot 004 \\
0 \cdot 083 \\
0 \cdot 364\end{array}$ & $\begin{array}{r}-0.19 \\
- \\
-0.90 \\
-0.72 \\
0.01\end{array}$ & $\begin{array}{l}0 \cdot 26 \\
0 \cdot 39 \\
0 \cdot 28 \\
0 \cdot 20\end{array}$ & $\begin{array}{l}0.232 \\
0.012 \\
0.008 \\
0.490\end{array}$ & $\begin{array}{r}0.17 \\
-0.17 \\
-0.28 \\
0 \cdot 10 \\
-0.01\end{array}$ & $\begin{array}{l}0 \cdot 27 \\
0 \cdot 27 \\
0 \cdot 21 \\
0 \cdot 25 \\
0 \cdot 19\end{array}$ & $\begin{array}{l}0 \cdot 263 \\
0 \cdot 270 \\
0 \cdot 095 \\
0 \cdot 352 \\
0 \cdot 474\end{array}$ \\
\hline $\begin{array}{l}\mathrm{FEV}_{1}(1): \\
\text { No } v \text { low/medium pressure } \\
\text { High } v \text { low/medium pressure } \\
>10 v<10 \text { minutes } \\
\text { Endotoxin exposuret } \\
\text { Ammonia exposuret }\end{array}$ & $\begin{array}{l}-0 \cdot 10 \\
-0 \cdot 31 \\
-0 \cdot 44 \\
-0 \cdot 26 \\
-0 \cdot 27\end{array}$ & $\begin{array}{l}0 \cdot 18 \\
0 \cdot 27 \\
0 \cdot 18 \\
0 \cdot 18 \\
0 \cdot 13\end{array}$ & $\begin{array}{l}0 \cdot 303 \\
0 \cdot 127 \\
0 \cdot 008 \\
0 \cdot 080 \\
0 \cdot 022\end{array}$ & $\begin{array}{l}-0.36 \\
-0.68 \\
-0.64 \\
-0.11\end{array}$ & $\begin{array}{l}0 \cdot 22 \\
0 \cdot 33 \\
0 \cdot 24 \\
0 \cdot 17\end{array}$ & $\begin{array}{l}0.057 \\
0.025 \\
0.006 \\
0.254\end{array}$ & $\begin{array}{l}-0.02 \\
-0.10 \\
-0.19 \\
-0.05 \\
-0.35\end{array}$ & $\begin{array}{l}0 \cdot 29 \\
0 \cdot 30 \\
0 \cdot 23 \\
0 \cdot 27 \\
0 \cdot 20\end{array}$ & $\begin{array}{l}0.476 \\
0.373 \\
0.201 \\
0.431 \\
0.043\end{array}$ \\
\hline $\begin{array}{l}\text { MMEF }(1 / \mathrm{s}) \text { : } \\
\text { No } v \text { low/medium pressure } \\
\text { High } v \text { low/medium pressure } \\
>10 v<10 \text { minutes } \\
\text { Endotoxin exposure } \\
\text { Ammonia exposure }\end{array}$ & $\begin{array}{l}-0.44 \\
-0.54 \\
-0.53 \\
-0.36 \\
-0.68\end{array}$ & $\begin{array}{l}0.32 \\
0.47 \\
0 \cdot 31 \\
0 \cdot 32 \\
0 \cdot 23\end{array}$ & $\begin{array}{l}0.086 \\
0.126 \\
0.046 \\
0.129 \\
0.002\end{array}$ & $\begin{array}{l}-0.86 \\
- \\
-0.59 \\
-0.70 \\
-0.37\end{array}$ & $\begin{array}{l}0.44 \\
0.66 \\
0.48 \\
0.33\end{array}$ & $\begin{array}{l}0.027 \\
0 \cdot 187 \\
0.078 \\
0.135\end{array}$ & $\begin{array}{l}-0.29 \\
-0.14 \\
-0.20 \\
-0.33 \\
-0.98\end{array}$ & $\begin{array}{l}0.47 \\
0.48 \\
0.37 \\
0.44 \\
0.33\end{array}$ & $\begin{array}{l}0 \cdot 271 \\
0 \cdot 387 \\
0 \cdot 290 \\
0 \cdot 233 \\
0.002\end{array}$ \\
\hline $\begin{array}{l}\text { PEF }(1 / s): \\
\text { No } v \text { low/medium pressure } \\
\text { High } v \text { low/medium pressure } \\
>10 v<10 \text { minutes } \\
\text { Endotoxin exposure } \\
\text { Ammonia exposure }\end{array}$ & $\begin{array}{r}0.24 \\
-0.85 \\
-1.20 \\
-0.47 \\
-0.77\end{array}$ & $\begin{array}{l}0.61 \\
0.88 \\
0.59 \\
0.60 \\
0.43\end{array}$ & $\begin{array}{l}0.350 \\
0.169 \\
0.023 \\
0 \cdot 220 \\
0.039\end{array}$ & $\begin{array}{l}-0.45 \\
-1.76 \\
-1.24 \\
-0.30\end{array}$ & $\begin{array}{l}0.81 \\
-1.23 \\
0.90 \\
0.62\end{array}$ & $\begin{array}{l}0.290 \\
0.080 \\
0.088 \\
0.318\end{array}$ & $\begin{array}{r}0.34 \\
-0.19 \\
-0.37 \\
0.00 \\
-1.00\end{array}$ & $\begin{array}{l}0.89 \\
0.91 \\
0.69 \\
0.84 \\
0.62\end{array}$ & $\begin{array}{l}0.353 \\
0.417 \\
0.296 \\
0.498 \\
0.056\end{array}$ \\
\hline
\end{tabular}

*Tested one sided; †log transformed exposure concentration; $b=$ regression coefficient.

transformed endotoxin and ammonia exposure was used in the analysis, which means that one unit change stands for an increase in exposure by a factor of $2 \cdot 72$. Such an increase in exposure to endotoxins was weakly associated with a decrease in FVC and $\mathrm{FEV}_{1}$ of about $250 \mathrm{ml}$ in the entire group (table 5, P < $0 \cdot 10)$. Over the range of exposures in our population (5-95 percentile: 54 to 196 $\mathrm{ng} / \mathrm{m}^{3}$ ), the estimated decrease was about 320 $\mathrm{ml}$. The exposure-response relations were much stronger in asymptomatic farmers, with estimated decreases of more than $900 \mathrm{ml}$ and $800 \mathrm{ml}$, respectively, over the range of exposures in our population. Exposures to ammonia were strongly and inversely related to all lung function variables except FVC. For example, an increase in exposure to ammonia by a factor of 2.72 was related to a decrease of $270 \mathrm{ml}$ in $\mathrm{FEV}_{1}$. The decrease in $\mathrm{FEV}_{1}$ over the exposures in our population (5-95 percentile: 0.6 to $3.2 \mathrm{mg} / \mathrm{m}^{3}$ ) was $450 \mathrm{ml}$. Relations between lung function and ammonia were for different variables $25 \%$ to $40 \%$ steeper in the group of symptomatic farmers than in the entire group. In the group of asymptomatic farmers negative but non-significant associations were found.

A disinfection procedure taking more than 10 minutes was significantly associated with lower values of most lung function variables (table 5). For example, FVC and $\mathrm{FEV}_{1}$ were estimated to be 480 and $440 \mathrm{ml}$ less, respectively, in farmers disinfecting for more than 10 minutes. Associations with disinfection procedures were not significant in symptomatic farmers. Overall, the best lung function was found if low or medium pressure was applied and the worst when high pressure was used. Low and medium pressures were taken together in the analysis as their association with lung function was similar. A significant decrease of about $20 \%$ was found for MMEF among asymptomatic workers. Dust exposure and type of disinfectant were not related to lung function, and did not influence other exposure-response estimates and were not included in the model. In similar models (table 5) with quantity of specific disinfectant used in one year added as an explanatory variable, quantity was inversely but not significantly associated with lung function in the entire group. In contrast, the associations with MMEF and PEF were highly significant among asymptomatic farmers. This effect was independent of duration and frequency of procedure. For each type of disinfectant, use of median quantity was associated with a similar decrease in lung function, which ranged on average from about $30 \%$ for $\mathrm{PEF}$, to $40 \%$ for MMEF.

The associations between respiratory symptoms and lung function and determinants of exposure were adjusted for all other variables in the models (tables 4 and 5). The different determinants of exposure were independent of each other but associated with respiratory health. The associations between lung function or chronic respiratory symptoms and other aspects of disinfection (table 2), were also evaluated. Of those, only type of application was more or less consistently related to lung function, but this effect is probably the same as that found with pressure as both variables were correlated.

\section{Discussion}

In our population of 1432 male pig farmers, including 299 working daily less than five hours in pig farming, $32.9 \%$ reported at least one chronic respiratory symptom. The prevalence of these symptoms has been shown to be invariably high in other studies of pig farmers 
in countries in Europe and north America. ${ }^{1-622}$ In our study a disinfection procedure of 10 minutes or more was much more prevalent among farmers with two or more than in farmers without chronic respiratory symptoms. Use of higher pressures (20 bar or more) during disinfection was positively related to chronic respiratory symptoms as well. Associations with duration and pressure were independent from each other. We are not aware of any other study that reported use of disinfectants as a potential respiratory health hazard for pig farmers. Exposures to ammonia, inhalable dust, and endotoxins were not associated with chronic respiratory symptoms.

Characteristics of the disinfection procedure (longer duration, no or high pressure, larger quantity of disinfectants) and exposure of endotoxins and ammonia were associated with lower base line lung function in pig farmers. Associations were most clearly present in asymptomatic farmers for disinfection procedure and endotoxin exposure. In this group the estimated effect of increase in endotoxin exposure by a factor of 2.72 and a disinfection procedure of more than 10 minutes were each associated with a decrease of about $15 \%$ in the different variables. The magnitude of the significant relations with ammonia exposure differed, and ranged from about $5 \%$ for $\mathrm{FEV}_{1}$ to $18 \%$ for $\mathrm{MMEF}$ in the entire population, but associations were $25 \%$ to $40 \%$ steeper in symptomatic farmers.

Symptomatic farmers were oversampled in our study. Data on lung function and associations with exposure as presented for the entire population are therefore not representative for the base population. Exposure-response relations for a representative sample of the base population are expected to be closer to those reported for asymptomatic than for symptomatic farmers. When the results for the asymptomatic farmers are being compared with other studies we can make the following observations. Similar patterns of lung function variables were found, with FVC, $\mathrm{FEV}_{1}$, and $P E F$ in the same range as control values, and MMEF lower than the control value. ${ }^{1-5} 723$ A decrease in MMEF may be regarded as an early change associated with flow limitation, even if the initial part of the spirogramme is unaffected. ${ }^{24}$

Duration of the disinfection procedure was consistently associated with lung function and respiratory symptoms. Multiple regression analyses showed that this could not be attributed to use of larger quantities of disinfectant in one year, type of disinfectant, other evaluated aspects of the disinfection procedure, or differences in exposures to dust, endotoxins, or ammonia. Potentially, this relation found for duration of disinfection reflected an association with level of ambient exposure concentration or critical time of exposure.

Most commonly used disinfectants contain quaternary ammonium compounds with or without aldehydes (glutaraldehyde, glyoxal, formaldehyde), or chloramine- $T$. In the scien- tific literature, several effects of exposure to chloramine- $T$ have been reported. These include respiratory symptoms such as cough, wheezing and dyspnoea, and immediate and late asthmatic reactions. Effects on eyes and upper respiratory system are reported either together with or without symptoms of the lower respiratory system. ${ }^{891125}$ Recently, two cases have been reported with occupational asthma due to exposure to disinfectants containing quaternary ammonium compounds. ${ }^{13} 14$ Glutaraldehyde has been shown to be able to induce occupational asthma by means of serial PEF measurements. ${ }^{10} 12$ Norbäck et $a l^{26}$ performed a cross sectional study on 39 workers in medical services exposed to glutaraldehyde concentrations below the Swedish occupational exposure limits, and 68 unexposed controls. They reported differences in symptom prevalence of the upper respiratory tract, but not of symptom prevalence of the lower respiratory tract. To our knowledge their study is the only one reporting prevalences of respiratory health effects in an occupational group exposed to either quaternary ammonium compounds, glutaraldehyde, or chloramine-T. Respiratory effects of exposure to formaldehyde, mostly from sources other than disinfectants, have frequently been reported. These include occupational asthma, effects on base line lung function and associations with respiratory symptoms in some occupational groups, although other studies fail to show such associations. ${ }^{27-30}$

In the entire group, the estimated decrease in FVC and $\mathrm{FEV}_{1}$ of about $250 \mathrm{ml}$ with an increase in exposure to endotoxins by a factor of 2.72 was of borderline significance. In asymptomatic farmers the associations were significant, and estimated decreases in lung function were $2 \cdot 5-3$ times larger (about $15 \%$ of median lung function values). The decrease in the entire population was similar to that reported by Heederik et $a l^{6}$ in a group of 62 farmers. Concentrations of endotoxins in swine confinement buildings and variation in exposure between people in that study were in the same range as in our study. They reported a decrease in FVC of $263 \mathrm{ml}(\mathrm{P}<0.10)$ and in $\mathrm{FEV}_{1}$ of $208 \mathrm{ml}(\mathrm{P}<0.05) / 100 \mathrm{ng} / \mathrm{m}^{3}$ increase in endotoxin concentration. Such an increase is similar to the difference between the 10th and 90th percentile of the exposure distribution in our study, which corresponds to an increase by a factor of nearly $2 \cdot 72$. Taking oversampling of symptomatic farmers into account, the exposure-response relation is expected to be about a factor of two steeper in our study. Zejda $\mathrm{et}^{\mathrm{al}} \mathrm{l}^{7}$ reported in a group of 46 pig farmers a borderline significant decrease in FVC, of $145 \mathrm{ml}$ with an increase by a factor of 2.72 in endotoxin concentration in swine buildings, about $40 \%$ less than in our

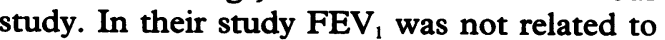
endotoxin concentration. They reported an endotoxin exposure that was five times higher than in our study, despite similar dust exposures. Endotoxin concentration multiplied by number of hours working in swine buildings, as an approximation of personal exposure, 
was strongly related to FVC $(P=0.02)$, and weakly related to $\mathrm{FEV}_{1}(P=0.06)$. It is not clear whether this finding can be attributed to number of hours alone, which might be related to any type of exposure. No detailed comparison can be made between our study and those of Heederik $e t a l^{6}$ and Zejda $e t a l{ }^{7}$ as exposure was not based on personal exposure measurements in their studies. Generally there is poor correlation between static air measurements and personal sampling. ${ }^{1931}$ It is unlikely that static measurements induced only systematic bias, as exposures largely depend on the activity of pigs caused by disturbance by the farmer, and by the farmer's own activity. ${ }^{2132}$

The inverse association between lung function and exposure to ammonia was not expected, as ammonia is hygroscopic and therefore the dose is generally expected to be low. In free form it will be captured in the upper part of the respiratory tract. It has been suggested that dust particles can act as carriers that bring ammonia into smaller airways, ${ }^{33} 34$ which may explain our results. In the epidemiological studies mentioned earlier ${ }^{6}$ reported exposures were three to seven times higher than in our study. Associations adjusted for confounding factors between exposure to ammonia and either base line lung function or chronic respiratory symptoms were not found or reported in these and other studies. Reports on effects of chronic exposure to ammonia at any level of exposure are sparse. Holness $e t a^{35}$ studied 58 workers exposed to on average $9.2 \mathrm{mg} / \mathrm{m}^{3}$ ammonia in the soda ash industry, but did not find differences in symptoms and lung function between exposure categories, or with control workers.

Exposure-response relations differed for respiratory symptoms and lung function. Also other studies in pig farming and the animal feed industry, with the same questionnaire and lung function test, showed this phenomenon. ${ }^{636}$ In addition, associations with lung function differed between symptomatic and asymptomatic farmers. There may be different reasons for these inconsistencies. Firstly, different biological mechanisms may be underlying these discrepancies. Secondly, symptomatic farmers may adjust their working practice to limit inhaled doses of pollutants, which they associate with symptoms. This may be done by avoiding activities with high (dust related) exposure, by using dust masks, and more subtle behavioural changes. Thirdly, symptomatic farmers may be more sensitive to normal ammonia exposure encountered in pig farming, whereas at these exposures ammonia does not cause respiratory symptoms in symptom free farmers.

There was no indication that discrepancies in relations between exposure and lung function could be attributed to acute effects of exposure before lung function testing in either asymptomatic or symptomatic farmers.

In conclusion, our results suggest that the aetiology of chronic respiratory health effects in pig farmers is multifactorial. Disinfectants were, until this study, not regarded as poten- tial health hazards. In our study, exposure to disinfectants was only based on qualitative information and quantity used. The relations need to be substantiated by actual exposure measurements. Associations with endotoxin exposures support the hypothesis that endotoxins are causally related to chronic respiratory health effects. Inconsistency in relations between reported symptoms and tested lung function, and in lung function between symptomatic and asymptomatic farmers requires more attention. It is expected that cross sectional studies can add little more to the insight into the aetiology of respiratory symptoms of pig farmers than has already been obtained from our study. Our study involved very labour intensive and costly field work campaigns. Small variations in exposure between people in the presence of relatively large variations within people, changing exposures over a longer period of time, the multifactorial aetiology of symptoms, and combined exposures require preferably prospective study designs, with an even more detailed measurement of exposure and investigation of health effects.

The study was supported by the Dutch Prevention Fund (Grant No 2821440), and the NCB Pig Farmers Association in The Southern Netherlands. We thank Dr Stijn Gielen for lung function testing and employees of the Animal Health Service in The Southern Netherlands and students for their Service in The Southern Ne
assistance in data collection.

1 Bongers P, Houthuijs D, Remijn B, Brouwer R, Biersteker $K$. Lung function and respiratory symptoms in pig farmers. Br $\mathcal{F}$ Ind Med 1987;44:819-23.

2 Holness DL, O'Blenis EL, Sass-Kortsak A, Pilger C Nethercott JR. Respiratory effects and dust exposures in Nethercott JR. Respiratory effects and dust exposures in hog confin

3 Dosman JA, Graham BL, Hall D, Pahwa P, McDuffie HH, Lucewicz $M$, To $T$. Respiratory symptoms and alterations in pulmonary function tests in swine producers in Saskatchewan: results of a survey of farmers. $\mathcal{f}$ Occup Med 1988;30:715-20.

4 Donham K, Haglind P, Peterson Y, Rylander R, Belin L. Environmental and health studies of farm workers in Swedish swine confinement buildings. $\mathrm{Br} \mathcal{F}$ Ind Med 1989;46:31-7.

5 Zejda JE, Hurst TS, Rhodes CS, Barber EM, McDuffie HH, Dosman JA. Respiratory health of swine producers. Focus on young workers. Chest 1993;103:702-9.

6 Heederik D, Brouwer R, Biersteker K, Boleij JSM Relationship of airborne endotoxin and bacteria levels in pig farms with the lung function and respiratory symptoms in farmers. Int Arch Occup Environ Health 1991; 62:595-601.

7 Zejda JE, Barber E, Dosman JA, Olenchock SA, McDuffie $\mathrm{HH}$, Rhodes C, Hurst T. Respiratory health status in swine producers relates to endotoxin exposure in the presence of low dust levels. F Occup Med 1994;36:49-56.

8 Bourne MS, Flindt MLH, Miles Walker J. Asthma due to industrial use of chloramine. $B M \mathcal{F} 1979 ; 2: 10-2$.

9 Dijkman JH, Vooren PH, Kramps JA. Occupational asthma due to inhalation of chloramine-T. I. Clinical asthma due to inhalation of chloramine-T. I. Clinical Arch Allergy Appl Immunol 1981;64:422-7.

10 Benson WG. Case report. Exposure to glutaraldehyde. f Soc Occup Med 1984;34:63-4

11 Blomqvist AM, Axelsson IGK, Danielsson D, Kiviloog J Ulander A, Zetterström $O$. Atopic allergy to chloramine- $T$ and the demonstration of specific IgE antibodies by the radioallergosorbent test. Int Arch Occup Environ Health 1991;63:363-5.

12 Chan-Yeung M, McMurren T, Catonio-Begley C, Lam S. Occupational asthma in a technologist exposed to glutaraldehyde. 7 Allergy Clin Immunol 1993;91:974-8.

13 Burge SP, Richardson MN. Occupational asthma due to indirect exposure to lauryl dimethyl benzyl ammonium chloride used in a floor cleaner. Thorax 1994;49:842-3.

14 Bernstein JA, Stauder T, Bernstein DI, Bernstein IL. A combined respiratory and cutaneous hypersensitivity combined respiratory and cutaneous hypersensitivity
syndrome induced by work exposure to quaternary syndrome induced by work exposure to quat

15 Biersteker K, Dijk WH van, Eissen JBMF, Geuns HA van. Ervaringen met geneeskundig onderzoek op CARA bij 
gemeentepersoneel te Rotterdam, 1970-71. Tijdschr Soc Geneeskd 1974;52:158-62.

16 Quanjer PH. Standardized lung function testing. Report of the Working Party on Standardization of Lung Function Tests. Bull Eur Physiopathol Respir 1983;19(suppl 5): $1-95$.

17 Willems JH, Hofschreuder P. A passive monitor for measuring ammonia. In: Allegrini I, Febo A, Perrino C, eds. Proceedings of the workshop on field intercomparison exercise on ammonia and ammonium measurement, $A$ pril 29 to May 4, 1990, Rome. Rome: Commission of the European Communities, Directorate-General for European Communities, Directorate-General for Science, Research and Developm
Pollution Research Report 37:113-8.)

18 Nederlands Normalisatie Instituut 1983. Fotometrische bepaling van het gehalte aan ammonium. NNI,1983. (NEN-6472.)

19 Smid T, Heederik D, Mensink G, Houba R, Boleij JSM. Exposure to dust, endotoxins, and fungi in the animal feed industry. Am Ind Hyg Assoc $\mathcal{F}$ 1992;53:362-8.

20 Hollander A, Heederik D, Versloot P, Douwes J. Inhibition and enhancement in the analysis of airborne endotoxin levels in various occupational environments. $\mathrm{Am}$ Ind Hyg Assoc $\mathcal{F}$ 1993;54:647-53.

21 Preller L, Heederik D, Kromhout H, Boleij JSM, Tielen MJM. Determinants of dust and endotoxin exposure of pig farmers: development of a control strategy using pig farmers: development of a control strategy using

22 Choudat D, Goehen M, Korobaeff M, Boulet A, Dewitte JD, Martin MH. Respiratory symptoms and bronchial reactivity among pig and dairy farmers. Scand $\mathcal{f}$ Work Environ Health 1994;20:48-54.

23 Zhou C, Hurst TS, Cockcroft DW, Dosman JA. Increased airways responsiveness in swine farmers. Chest 1991;99: 941-4.

24 American Thoracic Society. Lung function testing: selection of reference values and interpretative strategies. $A m$ Rev Respir Dis 1991;144:1202-18.

25 Wass U, Belin L, Eriksson NE. Immunological specificity of chloramine-T-induced IgE antibodies in serum from a sensitized worker. Clin Exp Allergy 1989;19:463-71.

26 Norbäck $D$. Skin and respiratory symptoms from exposure to alkaline glutaraldehyde in medical services. Scand $\mathcal{f}$ Work Environ Health 1988;14:366-71.

27 Burge PS, Harries MG, Lam WK, O'Brien IM, Patchett PA. Occupational asthma due to formaldehyde. Thorax 1985;40:255-60.

28 Nordman $\mathrm{H}$, Keskinen H, Tuppurainen-M. Formaldehyde asthma-rare or overlooked? f Allergy Clin Immunol 1985;75:91-9.

29 Horvath EP, Anderson H, Pierce WE, Hanrahan L, Wendlick JD. Effects of formaldehyde on the mucous membranes and lungs. A study of an industrial populamembranes and lungs. A study

30 Malaka T, Kodama AM. Respiratory health of plywood workers occupationally exposed to formaldehyde. Arch workers occupationally exposed
Environ Health 1990;45:288-94.

31 Cinkotai FF, Gibbs ACC, Sharpe TC. A comparison of exposure to airborne dust in cotton processing plants estimated from personal and workzone samples. Ann Occup Hyg 1984;28:347-52.

32 Zeitler-Feicht MH, Praml GJ, Riedel H. Die zeitliche Variation der Feinstaubbelastung der Luft im Mastschweinestall. Tiehygienische und arbeitsmedizinische Aspekte. Berl Münch Tierärtztl Wochenschr 1991;104: 84-9.

33 Donham KJ, Scallon LJ, Popendorf W, Treuhaft MW, Roberts RC. Characterization of dusts collected from
swine confinement buildings. Am Ind Hyg Assoc $\mathcal{F} 1986$; 47:404-10.

34 Schwartz DA, Landas SK, Lassise DL, Burmeister LF, Hunninghake GW, Merchant JA. Airway injury in swine confinement workers. Ann Intern Med 1992;116: 630-5.

35 Holness DL, Purdham JT, Nethercott JR. Acute and chronic respiratory effects of occupational exposure to ammonia. Am Ind Hyg Assoc ₹ 1989;50:646-50.

36 Smid T, Heederik D, Houba R, Quanjer PH. Dust- and endotoxin-related respiratory effects in the animal feed endotoxin-related respiratory effects in the anim
industry. Am Rev Respir Dis 1992;146:1471-9.

\section{Vancouver style}

All manuscripts submitted to Occup Environ Med should conform to the uniform requirements for manuscripts submitted to biomedical journals (known as the Vancouver style.)

Occup Environ Med, together with many other international biomedical journals, has agreed to accept articles prepared in accordance with the Vancouver style. The style (described in full in the $B M \mathcal{F}, 24$ February $1979, p 532$ ) is intended to standardise requirements for authors.

References should be numbered consecutively in the order in which they are first mentioned in the text by Arabic numerals above the line on each occasion the reference is cited (Manson ${ }^{1}$ confirmed other reports $^{2-5}$... .). In future references to papers submitted to Occup Environ Med should include: the names of all authors if there are seven or less or, if there are more, the first six followed by et al; the title of journal articles or book chapters; the titles of journals abbreviated according to the style of Index Medicus; and the first and final page numbers of the article or chapter. Titles not in Index Medicus should be given in full.

Examples of common forms of references are:

1 International Steering Committee of Medical Editors, Uniform requirements for manuscripts submitted to Uniform requirements for manuscripts subm
biomedical journals. $B r$ Med $₹$ 1979;1:532-5.

2 Soter NA, Wasserman SI, Austen KF. Cold urticaria: release into the circulation of histamine and eosinophil chemotactic factor of anaphylaxis during cold challenge. N Engl f Med 1976;294:687-90.

3 Weinstein L, Swartz MN. Pathogenic properties of invading micro-organisms. In: Sodeman WA Jr, Sodeman WA, eds. Pathologic physiology, mechanism of disease. Philadelphia: W B Saunders, 1974:457-72. 